Vol. 2, No. 2, Juli - Desember 2018

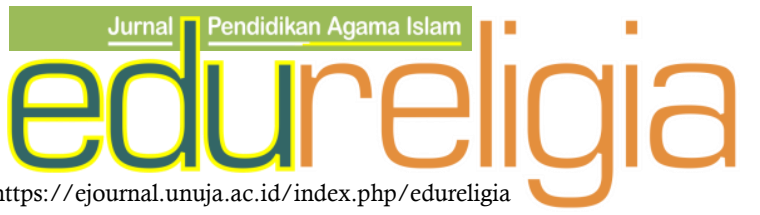

\title{
PROGRAM PEMBENTUKAN AKHLAK SISWA PADA MASA PUBERTAS (STUDI KASUS DI SMP TRI BHAKTI TEGALDLIMO BANYUWANGI TAHUN PELAJARAN 2018/2019
}

\author{
Ervin Sanika ${ }^{1}$; Fathi Hidayah ${ }^{2}$ \\ Institut Agama Islam Ibrahimy Banyuwangi, Banyuwangi, Jawa Timur, Indonesia
}

\begin{tabular}{l} 
Info Artikel \\
\hline Sejarah Artikel: \\
Diterima; Mei 2018 \\
Disetujui; Juni 2018 \\
Dipublikasikan; Agustus \\
2018
\end{tabular}

Keywords: moral development methods, puberty.

\begin{abstract}
School as an institution that is obliged to guide students to be strong, morally and hardworking must have breakthroughs in developing student morals, especially for the school level where students are in puberty. The activity carried out by Tri Bhakti Tegaldlimo Banyuwangi Middle School as an effort to assist students through puberty is a complete package because it is done through several methods. Habitual methods through religious activities, additional knowledge insights around puberty, and mentoring activities of talent and interest skills. In addition to the form of habituation, also do not forget to be provided with an example by the teacher through disciplinary activities and the most important thing is giving advice. These methods are the answers to the problems of today's youth education. Schools as parents do not only cram students with various forms of theoretical discourse, but also provide facilities as forming the moral virtues of their students.
\end{abstract}

(C) 2018 Fakultas Agama Islam Universitas Nurul Jadid 


\section{PENDAHULUAN}

Remaja merupakan suatu dimensi dimana seseorang berada dalam sebuah gerbang antara dua dimensi yang berbeda. Sebagaimana digambarkan bahwa masa remaja merupakan masa transisi, masa peralihan, masa penyesuaian, suatu tahapan yang harus dilalui oleh seorang manusia. Mengutip definisi remaja atau adolescene menurut para ahli, ternyata remaja tidak cukup didefinisikan sebagai grow to maturity saja, karena ada banyak faktor yang berubah terkait dengan perubahan usia seseorang pada masa ini.

Setidaknya ada beberapa sudut pandang dalam mendefinisikan masa remaja ini, Papalia dan Olds menggunakan sudut pandang usia dalam mendefinisikan masa remaja ini, yaitu batasan usia 11-20 tahun. Kemudian Anna Freud dan Hurlock kurang lebih mempunyai sudut pandang yang sama yaitu menekankan pada perubahan atau transisi secara psikoemosional dan hubungan sosial seseorang. Lebih jauh lagi, WHO memberikan pandanganya tentang masa remaja ini melalui perubahan pada diri sesorang secara individu (fisik dan seksual), psikologis, sosial dan ekonomi (Zarkasih Putro, 2017:25). Pandangan-pandangan tersebut menguatkan bahwa maturity bukan hanya matang secara fisik dan psikologis tetapi juga mapan dalam sebuah relasi sosial dan ekonomi.

Masa remaja tentu saja tak akan lepas dengan istilah pubertas. Menurut Desmita (2005: 192) pubertas (puberty) ialah suatu periode dimana kematangan kerangka dan seksual terjadi dengan pesat terutama pada awal masa remaja. Pubertas dalam Islam disebut dengan istilah baligh sebagai mana dalam al-Qur'an tanda-tanda orang menjelang dewasa terdapat pada surat AnNur ayat 59. Elizabeth B. Hurlock (2004: 139) mengemukakan bahwa batasan usia pubertas bagi perempuan antara umur 11-15 tahun dan bagi laki-laki antara umur 12-16 tahun.

Pada usia sekolah, masa pubertas ini masuk pada jenjang pendidikan menengah pertama. Untuk itu, sekolah setingkat ini harus mampu mengarahkan dan memfasilitasi masa transisi yang dialami anak didiknya selama masa pubertas. Sebagaimana pendapat Sukmadinata (2008:6), bahwa sekolah menengah jenjang SLTP/MTs mempunyai peranan yang sangat penting dalam memberikan dasar-dasar bagi pengembangan manusia unggul, bermoral dan pekerja keras, demi menjawab tantangan zaman.

Seperti halnya di SMP Tri Bhakti Tegaldlimo yang merupakan sekolah swasta di bawah naungan Lembaga Ma'arif NU yang konsen bukan hanya dengan kecerdasan intelektual tetapi juga mengedepankan kecerdasan spiritual yaitu dengan pembentukan akhlak siswa, untuk mewujudkan hal tersebut perlu dukungan dari semua pihak baik pemerintah, orang tua dan yang tidak kalah pentingnya adalah pengajar di sekolah terlebih guru PAI sangat berperan dalam pembentukan karakter dan akhlak siswa. Bukan hal mudah dalam pembentukan akhlak yang baik pada diri siswa dalam masa pubertas dimana masa ini merupakan masa transisi dari anak-anak ke dewasa yang meliputi semua perkembangan seperti perkembangan fisik, emosional, maupun sosial, pada masa ini mereka mengalami gejolak dan pencarian jati diri.

Dalam pencarian jati diri anak dalam masa pubertas mengalami situasi psikologis yang ingin melepas diri dari orang tua dan perasaan masih belum mampu untuk mandiri. Sebagai individu yang sedang mencari jati diri mereka sering mengalami kebingungan karena sering terjadi pertentangan pendapat dengan orang tua. Dari pertentangan tersebut menimbulkan kebingungan dalam dirinya sendiri maupun orang lain. (Asrori, 2005: 17)

Perubahan fisik cenderung lebih mendominasi karena merupakan salah satu ciri yang penting dari perkembangan masa puber. Perubahan fisik antara laki-laki dan perempuan sangatlah berbeda, pada laki-laki salah satunya bisa dilihat dari tumbuhnya kumis, perbahan suara, dan mimpi basah, sedangkan pada perempuan terjadi perubahan bentuk badan, panyudara dan mentruasi. Berkaitan dengan perubahan yang terjadi pada masa remaja atau puber diatas masa puber sering dikatakan sebagai masa kebingungan dikarenakan belum memiliki pengetahuan yang memadai mengenai perkembangan serta pematangan organ-organ tubuhnya.

SMP Tri Bhakti Tegaldlimo selalu mengedepankan kedisiplinan dan menanamkan nilai-nilai agama terlebih dalam pembentukan akhlak siswa. Hal ini dapat dilihat dari siswa di sekolah ini, sebagian besar dari mereka memiliki sikap santun dalam berperilaku, mempunyai 
kedisiplinan yang tinggi, dan jarang terjadi kasus kenakalan pada siswa, tetapi bukan tidak mungkin timbul masalah apalagi pada siswa SMP yang notabene pada masa ini merupakan masa pubertas yang mengalami perubahan jasmani, rohani maupun sosial.

Dalam kaitanya dengan kegiatan pengembangan akhlak siswa di SMP Tri Bhakti, dikembangkan berbagai kegiatan selain kegiatan intrakurikuler (materi-materi agama), yaitu kegiatan yang bersifat kokurikuler dan ekstrakurikuler. Melalui berbagai kegiatan inilah perubahan sifat dan perilaku siswa dapat tersalurkan dengan baik.

\section{KAJIAN KONSEPTUAL}

\section{Masa Pubertas}

1. Pengertian dan Batasan Usia Masa Pubertas

Menurut Desmita (2005: 192) pubertas (puberty) ialah suatu periode dimana kematangan kerangka dan seksual terjadi dengan pesat terutama pada awal masa remaja.

Pubertas dalam Islam disebut dengan istilah baligh sebagai mana dalam al-Qur'an tandatanda orang menjelang dewasa terdapat pada surat An-Nur ayat 59:

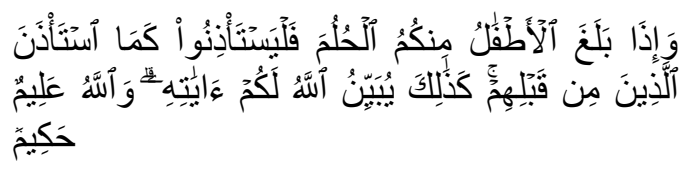

"Dan apabila anak-anakmu telah sampai umur baligh, maka hendaklah mereka meminta izin, seperti orang-orang yang sebelum mereka meminta izin. Demikianlah Allah menjelaskan ayat-ayat-Nya. Dan Allah Maha Mengetahui lagi Maha Bijaksana.(al Qur'an Terjemahan Depag RI, 2011: 359)"

Pada ayat-ayat diatas terdapat istilah kata "Baligh" yang dikaitkan dengan kata "alkhulm" antara lain berarti mimpi. Anak yang telah dewasa dilukiskan dengan kata mencapai khulm karena salah satu tanda kedewasaan adalah mimpi berhubungan seks atau "mukadimahnya" yang mengakibatkan keluarnya mani untuk anak laki-laki dan haid untuk anak perempuan. (Shihab, 2004: 394)

Elizabeth B. Hurlock (2004: 139) mengemukakan bahwa batasan usia pubertas bagi perempuan antara umur 11-15 tahun dan bagi laki-laki antara umur 12-16 tahun.
2. Pertumbuhan Rohani dan Jasmani Masa Pubertas

Masa pubertas merupakan periode yang sangat singkat di mana terjadi tumpang tindih antara masa akhir anak-anak dan permulaan masa remaja. Pertumbuhan dan perubahan baik fisik maupun mental sangatlah pesat. Oleh karena itu pertumbuhan pada masa pubertas dapat dibedakan menjadi dua yaitu:

1) Pertumbuhan rohani

Masa pubertas merupakan fase di mana seorang merasakan sesuatu yang belum pernah dirasakan sebelumnya. Hal ini terjadi sebagai akibat langsung dari stimulasi hormon-hormon pada anak, sehingga anak merasakan rangsangan-rangsangan khusus di dalam dirinya. Rangsangan tersebut adalah rangsangan hormonal yang menyebabkan suatu rasa tidak tenang, suatu perasaan yang belum pernah dialami pada masa anak-anak. (Sudarsono, 1989: 13)

Ciri utama pertumbuhan rohani dalam masa ini lebih menonjol dalam perbuatanperbuatan, sikap, perasaan, dan kehendak. Sikap yang menonjol antara lain: suka menentang terhadap orang tua, terombangambing dan tidak tenang, berperilaku tidak sopan, jarang berhati-hati, malas bekerja, suka membicarakan orang lain dan cepat tersinggung.

2) Pertumbuhan jasmani

Pada umumnya pertumbuhan jasmani bagi anak perempuan terjadi 2 tahun lebih awal dari anak laki-laki. Sedang pertumbuhan jasmani masa puber, terjadi empat perubahan fisik penting dimana tubuh anak dewasa yaitu perubahan ukuran tubuh, perubahan proporsi tubuh, perkembangan ciri-ciri seks primer, perkembangan ciri-ciri seks sekunder.

Tanda-tanda jasmani yang pada anak lakilaki antara lain: mengalami mimpi basah, mulai tumbuh bulu di beberapa tempat, adanya perubahan suara, tumbuhnya jakun, dan melebarnya bahu. Sedangkan pada perempuan antara lain: mengalami menstruasi pertama, perubahan suara, membesar dan menonjolnya payudara, melebarnya panggul, membesarnya pundak, menggempalnya kedua belah paha, disebabkan banyaknya lemak yang diserap disana. (Ridha, 2006: 42)

\section{Pembentukan Akhlak}

1. Pengertian akhlak

Menurut Kamus Besar Bahasa Indonesia (2008: 27) akhlak diartikan sebagai budi 
pekerti atau kelakuan. Sedangkan menurut pendekatan etimologi, perkataan "akhlak" berasal dari bahasa Arab jama' dari bentuk mufradnya "khuluqun" yang diartikan, budi pekerti, perangai, tingkah laku atau tabiat. Kalimat tersebut mengandung segi-segi persesuaian dengan perkataan "khalqun" yang berarti kejadian, serta erat hubungannya dengan "khaliq" yang berarti pencipta dan "makhluq" yang berarti yang diciptakan. (Gunawan, 2012: 4)

Definisi akhlak di atas muncul sebagai mediator yang menjembatani komunikasi antara khalik (pencipta) dengan makhluk (yang diciptakan) secara timbal balik, yang kemudian disebut sebagai hablum min Allah. Dari produk hablum min Allah yang verbal biasanya lahirlah pola hubungan antar sesama manusia yang disebut dengan hablum min annas (pola hubungan antar sesama makhluk).

Adapun pengertian akhlak secara terminologis merujuk pendapat beberapa ahli, diantaranya:

1) al-Ghazali dalam Nata (2002: 4) mengatakan bahwa akhlak adalah Sifat yang tertanam (terpatri) dalam jiwa yang darinya menimbulkan perbuatan-perbuatan yang gampang dan mudah tanpa memerlukan pemikiran dan pertimbangan (perenungan) terlebih dahulu.

2) Maskawih dalam Djatnika ( 1996: 26) mengatakan akhlak adalah Perangai itu adalah keadaan gerak jiwa yang mendorong kearah melakukan perbuatan dengan tidak menghajatkan pikiran.

3) Ahmad Amin dalam Ya'kub (1993:12) mengatakan akhlak adalah suatu ilmu yang menjelaskan arti baik dan buruk, menerangkan apa yang seharusnya dilakukan oleh manusia dalam perbuatan mereka dan menunjukkan jalan untuk melakukan apa yang harus diperbuat.

4) al-Jurjani dalam bukunya al-Ta'rifat dalam Mahmud (2004: 32) akhlak adalahIstilah bagi sesuatu sifat yang tertanam kuat dalam diri, yang darinya terlahir perbuatanperbuatan dengan mudah dan ringan, tanpa perlu berfikir dan merenung.

5) at-Tahanawi dalam Mahmud (2004: 34) akhlak adalah keseluruhannya kebiasaaan, sifat alami, agama, dan harga diri.

Berdasarkan pada beberapa penjelasan dan definisi akhlak di atas, dapat ditarik kesimpulan bahwa akhlak adalah segala sesuatu yang telah tertanam kuat atau terpatri dalam diri sesorang, yang akan melahirkan perbuatan-perbuatan yang tanpa melalui pemikiran atau perenungan terlebih dahulu. Artinya bahwa perbuatan itu dilakukan dengan reflek dan spotan tanpa dipikirkan terlebih dahulu. Jika sifat yang tertanam itu darinya muncul perbuatanperbuatan terpuji menurut rasio dan syariat maka sifat tersebut dinamakan akhlak yang baik (akhlak al-mahmudah). Sedangkan jika terlahir perbuatan-perbuatan buruk maka sifat tersebut dinamakan akhlak buruk (akhlak al-mamdudah).

\section{Tujuan Pembentukan Akhlak}

Sebelum merumuskan tujuan pembentukan akhlak, terlebih dahulu harus kita ketahui mangenai tujuan pendidikan Islam dan tujuan pendidikan akhlak, adapun tujuan utama dari pendidikan Islam ialah pembentukan akhlak dan budi pekerti yang sanggup menghasilkan manusia yang bermoral, jiwa yang bersih, kemauan yang keras, cita-cita yang benar dan akhlak yang tinggi, tahu arti kewajiban dan pelaksanaannya, menghormati hak asasi manusia, serta membedakan baik dan buruk, memilih suatu fadilah karena ia cinta pada fadilah, menghindari suatu perbuatan yang tercela, karena ia tercela, dan mengingat Tuhan dalam setiap pekerjaan yang mereka lakukan. Sedangkan tujuan pendidikan moral dan akhlak dalam Islam ialah untuk membentuk orang-orang berakhlak baik, keras kemauan, sopan dalam bicara dan perbuatan, mulia dalam tingkah laku dan perangai, bersifat bijaksana, sempurna, beradab, ikhlas, jujur, dan suci. (Al-Abrasy, 1970: 108-109).

Dari keterangan di atas, dapat ditarik rumusan mengenai tujuan pendidikan akhlak, yaitu membentuk akhlakul karimah. Sedangkan pembentukan akhlak sendiri itu sebagai sarana dalam mencapai tujuan pendidikan akhlak agar menciptakan menusia yang berakhlakul karimah.

3. Faktor-Faktor yang mempengaruhi Pembentukan Akhlak

Pada prinsipnya faktor-faktor yang mempengaruhi pembentukan akhlak ditentukan oleh dua faktor, yaitu faktor internal dan eksternal.

\section{1) Faktor internal}

Terdapat banyak hal yang mempengaruhi faktor internal,diantaranya adalah: 
- Insting atau Naluri

Insting adalah suatu sifat yang dapat menumbuhkan perbuatan yang menyampaikan pada tujuan dengan berfikir lebih dahulu kearah tujuan itu dan tidak didahului latihan perbuatan itu. Naluri merupakan tabiat yang dibawa sejak lahir yang merupakan suatu pembawaan yang asli. Para ahli psikologi membagi insting manusia sebagai pendorong tingkah laku ke dalam bagian diantaranya naluri makan, naluri berjodoh, naluri keibu bapak an, naluri berjuang dan naluri ber Tuhan. (Ya'kub, 1993: 58)

\section{- Adat atau Kebiasaaan (Habit)}

Kebiasaan adalah perbuatan yang selalu diulang-ulang sehingga mudah untuk dikerjakan. Faktor pembiasaan ini memegang peranan yang sangat penting dalam membentuk dan membina akhlak. Sehubungan kebiasaan merupakan perbuatan yang diulang-ulang maka hendaknya manusia memaksakan diri untuk mengulang perbuatan baik sehingga menjadi kebiasaan dan terbentuklah akhlak yang baik padanya.

\section{- Kehendak (Iradah)}

Merupakan kemauan untuk melangsungkan segala ide dan segala yang dimaksud, tanpa memperdulikan rintangan, ini merupakan kekuatan yang mendorong manusia untuk beperilaku sebab dari kehendak atau kemauan itulah menjelma suatu niat yang baik dan buruk dan tanpa kemauan semua kenyakinan, kepercayaan pengetahuan akan menjadi pasif tidak berguna bagi kehidupan.

\section{- Suara Hati}

Suara batin berfungsi untuk memperingatkan bahayanya perbuatan buruk dan berusaha untuk mencegahnya, disamping dorongan untuk melakukan perbuatan baik.

\section{- Keturunan}

Sifat yang diturunkan pada garis besarnya ada dua macam yaitu, sifat jasmaniyah dan sifat ruhaniyah.

\section{2) Faktor Eksternal}

Faktor eksternal yang mempengaruhi pembentukan akhlak, yaitu:
- Pendidikan

Pendidikan ikut mematangkan kepribadian manusia sehingga tingkah lakunya sesuai dengan pendidikan yang telah diterima oleh seseorang, baik pendidikan formal, informal maupun non formal. Betapa pentingnya faktor pendidikan karena naluri yang terdapat pada seseorang dapat dibangun dengan baik dan terarah. Oleh karena itu, pendidikan agama perlu dimanifestasikan melalui berbagai media baik pendidikan formal di sekolah, pendidikan informal di lingkungan keluarga, dan pendidikan non formal yang ada pada masyarakat.

\section{- Lingkungan (milie)}

Lingkungan adalah suatu yang melingkungi suatu tubuh yang hidup, seperti tumbuhtumbuhan, keadaan tanah, udara, dan pergaulan manusia hidup selalu berhubungan dengan manusia lainnya atau juga alam sekitar. Itulah sebabnya manusia harus bergaul dan dalam pergaulannya itu saling mempengaruhi pikiran, sifat dan tingkah laku.

\section{Metode Pembentukan Akhlak}

Beberapa metode yang biasa digunakan dalam pembentukan akhlak antara lain:

\section{Metode Keteladanan}

Keteladanan merupakan perbuatan yang patut ditiru dan dicontoh dalam praktik pendidikan, anak didik cenderung meneladani pendidiknya. Karena secara psikologis anak senang meniru tanpa memikirkan dampaknya. Amr bin Utbah berkata kepada guru anaknya:

Langkah pertama membimbing anakku hendaknya membimbing dirimu terlebih dahulu. Sebab pandangan anak itu tertuju pada dirimu maka yang baik kepada mereka adalah kamu kerjakan dan yang buruk adalah yang kamu tinggalkan. ( Sa'aduddin, 2006: 89)

a) Metode Latihan dan Pembiasaan.

Mendidik dengan melatih dan pembiasaan adalah mendidik dengan cara memberikan latihan-latihan terhadap suatu norma tertentu kemudian membiasakan untuk mengulangi kegiatan tertentu tersebut berkali-kali agar menjadi bagian hidupnya, 
seperti sholat, puasa, kesopanan dalam bergaul dan sejenisnya.

- Metode mauidzah (nasihat)

Mauidzah berarti nasihat. Rasyid Ridha mengartikan mauidzah adalah nasihat peringatan atas kebaikan dan kebenaran dengan jalan apa saja yang dapat menyentuh hati dan membangkitkannya untuk mengamalkan dalam al-Qur'an juga menggunakan kalimat-kalimat yang menyentuh hati untuk mengarahkan manusia kepada ide yang dikehendakinya.

- Metode reward dan sanksi (punishment)

Jika pembentukan akhlak tidak berhasil dengan metode keteladanan dan pemberian pelajaran, beralihlah kepada metode reward dan sanksi. Peranan reward sangat mempengaruhi dalam perilaku siswa sebab manusia selalu memiliki cita-cita, harapan, dan keinginan. Maka dengan metode ini seorang melakukan perbuatan baik atau berhasil berupa kinerja tertentu yang diberikan hadiah yang menarik sebagai imbalan. Sebaliknya metode sanksi atau punishment merupakan kebalikan dari reward yaitu jika siswa melakukan kesalahan atau melakukan tindakan yang buruk maka akan mendapatkan sanksi.

\section{METODE}

Jenis penelitian ini, penulis menggunakan pendekatan penelitian kualitatif dengan jenis penelitian deskriptif. Penelitian deskriptif adalah penelitian yang dilakukan dengan menjelaskan atau menggambarkan variable masa lalu dan masa sekarang atau sedang terjadi (Arikunto, 2006: 10). Adapun lokasi penelitian ini adalah berada di SMP Tri Bhakti Tegaldlimo Kabupaten Banyuwangi. Adapun waktu penelitian mulai bulan Mei sampai bulan Oktober 2018.

Adapun sumber data yang digunakan dalam penelitian ini adalah:

1. Sumber data primer, yaitu data yang diperoleh dari sumbernya secara langsung dan yang menjadi sumber data primer adalah bentuk kegiatan dan siswa.

2. Sumber data sekunder, yaitu data yang diperoleh dari data yang sudah ada dan mempunyai hubungan dengan masalah yang diteliti, atau sumber data pelengkap yang berfungsi melengkapi data-data yang diperlukan oleh kepala sekolah yang berupa dokumen-dokumen.
Penelitian ini menggunakan tiga jenis metodedan teknik pengumpulan data yaitu: observasi, wawancara dan dokumentasi. Untuk menganalisis data, digunakan teknik analisis data Milles dan Huberman yaitu: pengumpulan data, reduksi data, display data dan penarikan kesimpulan.

\section{HASIL}

SMP Tri Bhakti Tegaldlimo Banyuwangi adalah lembaga pendidikan di bawah naungan yayasan LP. Ma'arif NU Banyuwangi yang didirikan oleh MWC NU Kecamatan Tegaldlimo pada tahun 1974. SMP Tri Bhakti Tegaldlimo saat ini memiliki 13 rombel, yang terdiri dari kelas VII berjumlah 4 rombel, kelas VIII berjumlah 4 rombel, dan kelas IX berjumlah 5 rombel dengan jumlah siswa seluruhnya ada 335 siswa. Meskipun jumlah siswa di SMP Tri Bhakti Tegaldlimo yang lumayan banyak untuk ukuran sekolah swasta yang berada di wilayah Tegaldlimo, siswa SMP Tri Bhakti jarang terjerat dalam masalah kenakalan remaja apalagi masa SMP merupakan masa pubertas merupakan masa transisi antara masa anak-anak ke masa dewasa, banyak perubahan baik fisik maupun psikologis. Hal tersebut dapat terwujud berkat kerjasama yang solid semua stakeholder pendidikan, orang tua, pengurus, terutama pengelola yang berhadapan langsung dengan siswa disekolah, yaitu dari kepala sekolah, tenaga kependidikan, dan tenaga pendidikan.

Pembentukan akhlak pada masa pubertas yang diterapkan di SMP Tri Bhakti Tegaldlimo dengan kegiatan seperti, sholat dhuha berjama'ah, pembacaan al Qur'an one week one juz, kegiatan bedah kitab risalatul makhid, sholat dhuhur berjama'ah, kegiatan ekstrakulikuler keagamaan untuk menyalurkan bakat dan minat siswa seperti hadrah dan khataman al Qur'an. Adapun penjabaran kegiatan-kegiatan tersebut adalah sebagai berikut:

\section{a. Sholat Dhuha Berjama'ah}

Kegiatan sholat dhuha berjama'ah di SMP Tri Bhakti Tegaldlimo dilaksanakan setiap hari oleh semua siswa, dewan guru dan karyawan, diawali pukul 06.15 WIB, pengurus OSIS yang piket mulai menata tikar dihalaman sekolah, sembari menunggu siswa lain berkumpul siswa membaca sholawat nariyah menggunakan pengeras suara, tepat pukul 06.30 WIB guru PAI memberi perintah kepada siswa yang ditunjuk sebagai imam sholat dhuha untuk segera memulai pelaksanaan sholat dhuha 
sembari membimbing siswa untuk meluruskan shaf sholat.

Dalam pelaksanaan sholat dhuha ada beberapa siswi yang sedang haid dan tidak bisa mengikuti sholat dhuha, untuk mengantisipasi agar mereka tidak gaduh, guru PAI berinesiatif menyendirikan mereka ke ruang terdekat untuk memulai berdzikir tak lupa guru mengabsen siswa perempuan tersebut. Setelah sholat dhuha selesai siswa secara bersama-sama membaca sholawat nurul jannah, do'a sholat dhuha, sholawat nariyah dan asmaul khusna, setelah selesai guru PAI memberi ceramah singkat dan evaluasi dalam pelaksanaan sholat dhuha, masih ditemui beberapa siswa yang bergurau saat pelaksanaan dan terlambat mengikuti sholat dhuha berjama'ah, beliau berharap agar kedepannya siswa lebih disiplin lagi, dan siswa lebih khusyuk dalam melaksanakan sholat. (Observasi hari Jum'at, tanggal 20 Juli 2018)

\section{b. Pembacaan al Qur'an One Week One Juz}

Dalam Observasi pada hari sabtu tanggal 21 Juli 2018, pembacaan al Qur'an One Week One Juz di SMP Tri Bhakti Tegaldlimo dimulai pada pukul 07.00 WIB setelah sholat dhuha dan dzikir, Bapak Qujatul Nguyun, S.Pd.I. mulai mengkondisikan siswa agar segera bergegas mengambil al Qur'an, siswa yang mendapat giliran piket memimpin membaca al Qur'an untuk segera kedepan, setelah memastikan semua siswa membawa al Qur'an masing-masing beliau mengintrusikan agar dimulai, dalam pelaksanaan pembacaan al Qur'an guru PAI dibantu guru lainnya memantau jalannya kegiatan ada beberapa siswa yang bergurau kemuadian bapak Qujatul Nguyun menyuruh salah satu siswa tersebut untuk maju kebarisan paling depan untuk dipisahkan agar tidak bergurau lagi, kegiatan ini selesai pukul 07.30 WIB. Kegiatan ini juga dikuatkan dengan keterangan dari Bapak Qujatul Nguyun, S.Pd.I:

"Ya tentu ada..pembentukan akhlak pada masa puber tidak cukup dengan satu kegiatan, kegiatan One Week One Juz yaitu membaca al Qur'an sebanyak 1 Juz setiap hari sabtu diharapkan siswa dapat mendekatkan diri kepada Allah serta dapat menumbuhkan kecintaan membaca kitab suci dan lebih lanjut siswa dapat mengamalkan dikehidupan sehari-hari isi dari al Qur'an itu sendiri." (Wawancara dengan Bapak Qujatul Nguyun, S.Pd.I. Hari Jum'at, Tanggal 20 Juli 2018 pukul 08.00 WIB).

\section{c. Bedah Kitab Risalatul Makhid}

Siswa pada masa puber ditandai salah satunya dengan keluarnya darah haid atau menstruasi pada anak perempuan hal ini juga perlu ditangani dengan tepat oleh pihak sekolah khususnya oleh guru agama islam di SMP Tri Bhakti Tegaldlimo dengan mengadakan kegiatan bedah kitab risalatul makhid yang dilaksanakan setiap hari sabtu pukul 07.10 WIB dengan pemateri Guru Agama Islam Bapak Qujatul Nguyun. Kegiatan tersebut dimulai dengan mengabsen siswa, beliau mengecek absen dengan tujuan untuk memastikan kalaukalau ada siswa yang berbohong tidak haid mengaku haid agar tidak mengikuti sholat dhuha maupun sholat dhuhur berjama'ah ataupun jika ada siswa yang tidak bisa menghitung masa haid yang benar karena mengalami masa istikhadoh. Setelah mengabsen guru mulai dengan evaluasi materi minggu sebelumnya tentang pengertian darah haid dan darah istikhadoh, ternyata siswa masih rancu dan bingung bapak Qujatul Nguyun, S.Pd.I. mengulang kembali materi tersebut dengan sabar dan telaten, kemudian mulai membuka sesi tanya jawab, awalnya siswa masih malu untuk menceritakan masalah yang mereka alami pada waktu haid, tetapi bapak Qujatul Nguyun mulai mencairkan suasana dan meyakinkan kepada siswa bahwa hal tersebut bukan hal yang memalukan dan tabu dan bagi anak perempuan adalah wajib mengetahui hukumnya sebab menyangkut kapan kita melaksanakan ibadah wajib seperti, sholat, puasa dan apa yang diharamkan ketika sedang haid. Setelah mendengar perkataan guru siswa satu persatu mulai bertanya kepada bapak Qujatul Nguyun, ternyata masalah yang dihadapi siswa beragam, tepat pukul 07.30 WIB kegiatan bedah kitab selesai dan siswa langsung kembali ke kelas masing-masing untuk memulai KBM. (Observasi pada hari sabtu, tanggal 21 Juli 2018).

\section{d. Sholat dhuhur berjama'ah}

Bukan hanya sholat dhuha berjama'ah di SMP Tri Bhakti juga melaksanakan sholat dhuhur berjama'ah yang dilaksanakan setiap hari kecuali hari jum'at dimulai pukul 11.30 WIB. Bapak Qujatul Nguyun, S.Pd.I. mengintruksikan kepada siswa untuk adzan dhuhur di masjid, dibantu guru lain mengecek tiap kelas agar semua segera mengambil wudhlu dan segera menuju masjid, dan untuk siswa perempuan yang berhalangan diintruksikan untuk membersihkan kelas masing-masing, 
pelaksanaan sholat dhuhur selesai pukul 12.00 WIB . (Observasi pada Hari Sabtu, Tanggal 21 Juli 2018).

\section{e. Kegiatan Ekstrakulikuler Keagamaan} Hadrah

Hadrah merupakan seni musik yang bernuansa islami dan menjadi salah satu kegiatan ekstrakulikuler yang ada di SMP Tri Bhakti Tegaldlimo yang dilaksanakan setiap hari kamis pukul 14.00 WIB yang diikuti oleh siswa kelas 7, 8 dan 9 yang berminat, kegiatan ini dibimbing langsung oleh guru agama bapak Qujatul Nguyun, S. Pd.I.

Mengenai kegiatan di atas peneliti mewawancarai Bapak Qujatul Nguyun, S.Pd.I. selaku Guru Agama Islam dan pembimbing ekstrakulikuler hadarah tentang tujuan adanya kegiatan tersebut:

"Tujuannya tidak lain untuk menanamkan nilai-nilai akhidah melalui syair hadrah yang berisi tentang ke-Esaan Allah SWT juga pujian terhadap Rasulullah SAW sehingga dapat meningkatkan keimanan, nilai akhlak dimana siswa terbiasa bersikap dan berkatakata yang baik, nilai ibadah yang merupakan bentuk penghambaan atau penyembahan, nilai sosial yaitu dapat menjalin silaturrahmi, solidaritas, dan menambah ilmu." (Wawancara Hari Sabtu, Tanggal 21 Juli 2018, Pukul 12.20 WIB)

\section{f. Khataman al Qur'an}

Membaca al Qur'an merupakan kegaiatan pembiasaan yang ada di SMP Tri Bhakti Tegaldlimo, bukan hanya kegiatan one week one juz saja tetapi khataman al Qur'an juga diprogramkan oleh sekolah, dengan bekerjasama dengan semua pihak baik pengurus, pengelola sekolah, wali murid, dan masyarakat. Khataman al Qur'an di SMP Tri bhakti dilaksankan tidak hanya di masjid sekolah tetapi dilaksanakan di masjid atau mushola desa domisili siswa SMP Tri Bhakti, kegiatan ini dilaksanakan 2 minggu sekali, pada hari minggu dimulai pukul 08.00 WIB sampai selesai, pesertanya adalah OSIS dan siswa yang tinggal di tempat khataman al Qur'an itu sendiri serta dikawal langsung oleh guru agama, kesiswaan dan guru lain.

Mengenai kegiatan khataman al Qur'an tersebut peneliti mewawancarai Bapak Agus Riono, S.Pd. selaku Guru Bahasa Inggris dan Kesiswaan SMP Tri Bhakti Tegaldlimo, beliau mengatakan :

"Pembentukan akhlak pada masa pubertas dengan mengarahkan dan membina siswa tidak hanya waktu jam pembelajaran tetapi dengan kegiatan ekstrakulikuler keagamaan pubertas bukanlah semata-mata tanggung jawab Guru PAI semata, tetapi semua stakeholder pendidikan, sekolah sendiri mempunyai inisiatif seperti khataman Qur'an yang dilaksanakan 2 minggu sekali pada hari minggu pukul 08.00 WIB." (Wawancara di SMP Tri Bhakti Tegaldlimo tanggal 23 Juli 2018 , pukul 10.00 WIB)

\section{g. Keteladanan guru}

Adapun bentuk keteladan guru PAI di SMP Tri Bhakti merupakan contoh buat siswa dalam mematuhi tata tertib sekolah seperti:

\section{1) Disiplin Waktu}

Disiplin adalah sikap menaati peraturan, begitu juga di SMP Tri Bhakti mempunyai peraturan disetiap aspek, seperti jam masuk sekolah, pukul 06.30 WIB gerbang sudah ditutup dan siswa tidak diperkenankan masuk jika lewat jam tersebut. Tetapi terkadang masih ada saja siswa yang terlamabat dengan berbagai alasan, maka dari itu guru yang notabene panutan bagi siswa juga harus memberikan contoh salah satunya tentang disiplin waktu. Berikut wawancara peneliti dengan Bapak Qujatul Nguyun, S.Pd.I sebagai guru PAI di SMP Tri Bhakti Tegaldlimo, beliau mengatakan :

"Istilah lain dari guru kan "digugu dan ditiru", semua gerak gerik kita mau tak mau akan diamati oleh anak-anak, apalagi anak saat masa puber yang masih dalam tahap pencarian jati diri, ada beberapa dari mereka memandang guru sebagai role mode, oleh karena itu sebagai guru yang harus memberi contoh yang baik seperti, disiplin waktu, berangkat pagi dan menyambut mereka didepan gerbang, dalam segi penampilan.. memakai pakaian yang sopan, rapi,.. dalam berbicara ya..kita harus hati-hati berbicara sopanlah.."

(Wawancara di SMP Tri Bhakti Hari Senin, Tanggal 23 Juli 2018 Pukul 11.00 WIB)

Hal tersebut diperkuat oleh Kepala Sekolah SMP Tri Bhakti Tegaldlimo, Drs. H. Mardi, M.Pd. beliau mengatakan:

"Peran guru itu multifungsi, bisa menjadi orang tua, teman bahkan idola yang dicontoh oleh anak-anak..ketika menjadi orang tua ya harus mengayomi, sebagai teman bisa menjadi tempat curhat dan memberi solusi, sebagai idola ya seharusnya memberi contoh yang baik biar bisa ditiru, bukan hanya satu guru tapi semua guru harus menjadi contoh yang baik seperti 
datang lebih pagi." (Wawancara di SMP Tri Bhakti Tegaldlimo Hari Senin, Tanggal 23 Juli 2018 Pukul 11.15 WIB)

Seperti peneliti lihat pada observasi pada tanggal 24 Juli 2018 pukul 06.00 WIB Guru PAI Bapak Qujatul Nguyun, S. Pd.I. sudah datang dan menunggu siswa di depan gerbang bersama dengan guru piket lainnya, siswa mengantri untuk bersalaman dengan guru, ada beberapa siswa bajunya tidak dimasukkan, Bapak Qujatul Nguyun menegur agar bajunya dimasukkan, setelah pukul 06.30 WIB pintu gerbang ditutup.

2) Disiplin dalam berpakaian (penampilan)

Disiplin dalam berpakaian (penampilan) juga menjadi peraturan di SMP Tri Bhakti Tegaldlimo, hal itu terlihat adaya ketentuan dalam model seragam para siswa, tapi seiring waktu dengan perubahan bentuk fisik dan kepribadian dalam masa puber, ada saja yang ingin coba-coba dengan model yang mereka lihat di tv ataupun dimajalah. Oleh karena itu guru terutama guru agama islam harus mencontohkan berpakaian yang islami, rapi dan sopan. Dan untuk menciptakan kedisiplinan dalam berpakaian guru agama islam bapak Qujatul Nguyun, S.Pd.I. berkoordinasi dengan kesiswaan untuk melaksanakan sidak, berikut wawancara dengan Bapak Agus Riono, S.Pd. Selaku kesiswaan SMP Tri Bhakti Tegaldlimo:

"Guru PAI bersama Kesiswaan mempunyai agenda bulanan, yaitu melakukan sidak kediplinan yang dibantu guru lain. Diantara yang disidak adalah siswa yang membawa HP, menyemir rambut selain hitam, menggunakan make up yang terlalu tebal dan seragam yang menunjukkan lekuk tubuh khususnya siswa perempuan. Juga pada siswa laki-laki yang memakai anting dan kalung." (Wawancara di SMP Tri Bhakti Tegaldlimo Hari Selasa, Tanggal 24 Juli 2018, pukul 08.30 WIB).

\section{3) Disiplin Sikap}

Disiplin sikap ini berkaitan dengan tingkah laku siswa SMP Tri Bhakti tegaldlimo seperti bertutur kata sopan, membungkuk ketika bertemu dengan guru serta mengucapkan salam terlebih dahulu, jujur, menjaga kebersihan dan sebagainya. Mengenai hal tersebut peneliti mewawancarai guru PAI Bapak Qujatul Nguyun, S.Pd.I. beliau mengatakan:

"Sikap mencerminkan kepribadian seseorang, sebagai guru yang menjadi contoh bagi semua siswa kita juga harus mencontohkan hal yang baik, misalnya kita berbicara sopan perhatian terhadap peserta didik." (Wawancara di SMP Tri Bhakti Tegaldlimo Hari Selasa, Tanggal 24 Juli 2018, Pukul 09.00 WIB)

\section{h. Memberi nasihat}

Nasihat merupakan cara yang cukup berhasil dalam pembentukan akhlak siswa pada masa puber, sebab nasihat memiliki pengaruh yang cukup besar dalam membuka mata hati anak-anak dengan memberikan kesadaran dan martabat yang luhur, menghiasi dengan akhlak yang mulia serta membekali dengan prinsip-prinsip islam.

Hal tersebut sesuai dengan pernyataan guru PAI SMP Tri Bhakti Tergaldlimo Bapak Qujatul Nguyun, S.Pd.I, tentang pemberian nasihat sebagai salah satu metode dalam pembentukan akhlak siswa dalam masa puber:

"Setiap karakter anak itu berbeda, kadang ada yang tertutup tapi banyak pula yang terbuka dengan masalah mereka, pintarpintarnya kitalah bagaimana membuat mereka bisa terbuka dengan masalah mereka, kenakalan remaja bukan sematamata anak itu mau seperti itu tapi mereka kebanyakan mencari perhatian, pelarian, kita sebagai guru apalagi guru agama harus terus menanamkan akhlakkul karimah, prinsipprinsip islam, menasehati diminta maupun tidak oleh anak-anak, biasanya terlihat jika kita memperhatikan siswa di kelas murung tidak konsen dalam proses pembelajaran jelas mereka mempunyai masalah, biasanya saya memanggil siswa tersebut diluar jam pelajaran dengan maksud menanyakan apakah ada masalah dan memberi solusi ataupun nasihat dan terus mendekatkan diri kepada Allah SWT." (Wawancara di SMP Tri Bhakti Tegaldlimo Hari Selasa, Tanggal 24 Juli 2018 Pukul 09.40 waktu jam istirahat).

\section{PEMBAHASAN}

Kegiatan pembentukan akhlak siswa pada masa pubertas di SMP Tri Bhakti Tegaldlimo dilakukan melalui berbagai cara baik kegiatan yang bersifat ritual keagamaan, maupun pengayaan materi dan pengembangan keterampilan. Hampir semua metode pembentukan akhlak digunakan oleh pihak sekolah mengingat besarnya tanggung jawab sekolah akan hal tersebut. Berbagai kegiatan tersebut dapat ditarik dalam bentuk metode-metode sebagai berikut:

a. Metode Pembiasaan 
Pembiasaan menurut Gunawan (2012: 93) merupakan sesuatu yang sengaja dilakukan secara berulang-ulang agar sesuatu itu dapat menjadi kebiasaaan. Adapun kegiatan pembiasaan di SMP Tri Bhakti Tegaldlimo tersebut sebagai berikut:

\section{1) Sholat Dhuha berjama'ah}

Dalam kegiatan sholat dhuha berjama'ah di SMP Tri Bhakti Tegaldlimo yang dilaksanakan setiap pagi pukul 06.30 WIB diharapkan dapat membentuk akhlak siswa dengan pembelajaran sholat sunah, disini siswa dituntut untuk disiplin, mandiri, dan bertanggung jawab. Bukan hanya siswa saja tetapi seluruh guru dan karyawan juga melaksankan sholat dhuha berjama'ah, peran guru PAI sebagai pembimbing dalam kegiatan ini juga terlihat seperti pengaturan shaf sholat saat sholat dhuha, pemberian pembinaan dengan ceramah singkat setelah sholat dhuha.

\section{2) Pembacaan al Qur'an One Week One Juz}

Kegiatan pembentukan akhlak lainnya di SMP Tri Bhakti Tegaldlimo yang dilaksankan setiap hari sabtu pukul 07.00 WIB setelah sholat dhuha, dalam kegiatan ini diharapkan dapat meningkatkan kemampuan siswa dalam membaca al Qur'an serta memahami dan mengamalkan isi yang terkandung dalam al Qur'an dikehidupan sehari-hari.

\section{3) Bedah Kitab Risalatul Makhid}

Kegiatan ini rutin dilaksanakan setiap hari sabtu pukul 07.10 WIB khusus bagi siswa perempuan yang sedang mengalami haid atau menstruasi, pemateri sendiri adalah guru PAI bapak Qujatul Nguyun, S.Pd.I. dengan tujuan dapat memberikan bimbingan dan pengetahuan yang lebih mendalam tentang masalah haid menurut hukum islam.

\section{4) Sholat Dhuhur Berjama'ah}

Dengan kegiatan sholat dhuhur secara berjama'ah yang menjadi kegiatan pembiasaan di SMP Tri Bhakti Tegaldlimo yang dilaksankan setiap hari pukul 11.30 WIB kecuali hari jum'at diharapkan dapat membentuk kedisiplinan siswa dalam melakukan setiap kegiatan, apalagi shalat merupakan ibadah wajib maka harus dilakukan tepat pada waktunya sehingga mereka tidak merasa terbebani melaksankan itu semua.

\section{5) Ekstrakulikuler Keagamaan Hadrah}

Pembentukan akhlak siswa pada masa pubertas dilakukan dengan berbagai cara,
Guru PAI bekerjasama dengan kesiswaan didukung penuh oleh pengelola sekolah, kepala sekolah dan guru lainnya, membentuk kegiatan ekstrakulikuler hadrah yang dilaksanakan setiap hari kamis pukul 14.00 WIB yang dibimbing langsung oleh guru PAI SMP Tri Bhakti Tegaldlimo Bapak Qujatul Nguyun, S.Pd.I., disamping sebagai kegiatan untuk menyalurkan minat siswa agar tidak terjerumus dalam kegiatan yang negatif, dalam hadrah sendiri terkandung nilai-nilai pendidikan islam diantaranya:

a) Nilai akhidah yang terdapat pada syair hadrah yang berisi tentang ke-Esaan Allah SWT juga pujian terhadap Rasulullah SAW sehingga dapat meningkatkan keimanan,

b) Nilai akhlak dimana siswa terbiasa bersikap dan berkata-kata yang baik,

c) Nilai ibadah yang merupakan bentuk penghambaan atau penyembahan,

d) Nilai sosial yaitu dapat menjalin silaturrahmi, solidaritas, dan menambah ilmu.

\section{6) Khataman al Qur'an}

Khataman al Qur'an yang dilaksankan setiap dua minggu sekali setiap hari minggu pukul 08.00 WIB sampai selesai yang bertempat di masjid lingkungan tempat tinggal siswa SMP Tri Bhakti Tegaldlimo. Kegiatan ini selain bertujuan untuk pembiasaan dengan kegiatan positif juga untuk menyambung tali silaturrahim dengan wali murid serta masyarakat yang diharapkan pemantauan terhadap anak lebih mudah dengan kerjasama semua pihak.

\section{b. Metode Keteladanan}

Pembelajaran sangat penting dalam rangka membentuk akhlak mulia bagi siswa yang peran pendidik sebagai model diajar. Karena gerak gerik guru sebenarnya selalu diperhatikan oleh setiap murid. Guru berperan sebagai model (contoh) dengan mencontohkan nilai keteladanan. Ini sesuai dengan teori Heri Gunawan sebagai berikut:

Guru atau pendidik adalah orang yang menjadi anutan anak peserta didiknya. Setiap anak mula-mula mengagumi kedua orang tuanya. Semua tingkah laku orang tua ditiru oleh anak-anaknya. Tetapi ketika anak itu sekolah maka ia mulai meneladani atau meniru apapun yang dilakukan oleh gurunya. Oleh karenanya guru perlu memberikan keteladanan yang baik kepada para peserta didiknya. 2012: 91-92) 
Nilai keteladanan yang dicontohkan oleh guru PAI di SMP Tri Bhakti bertujuan agar siswa mematuhi tata tertib sekolah dengan meningkatkan kedisiplinan diberbagai aspek seperti:

a. Disiplin waktu, dapat dilihat dengan pukul 06.00 WIB Guru PAI Bapak Qujatul Nguyun, S.Pd.I. sudah berada di sekolah dan menunggu siswa di depan gerbang sekolah, hal ini bertujuan agar tidak ada siswa yang datang terlambat datang ke sekolah.

b. Disiplin dalam berpakaian (penampilan), Guru PAI mencontohkan berpakaian yang islami, rapi dan sopan. Berkoordinasi dengan kesiswaan dan guru lain melakukan sidak terhadap siswa yang berpakaian tidak sesuai dengan ketentuan sekolah, make up tebal pakaian yang melihatkan lekuk tubuh bagi siswa perempuan, memakai asesoris untuk siswa laki-laki.

c. Disiplin sikap, sikap yang dicontohkan guru PAI SMP Tri Bhakti Tegaldlimo dengan bertutur kata sopan, perhatian terhadap peserta didik.

Sesuai dengan teori yang disampaikan oleh Abduin Nata, bahwa Akhlak yang baik tidak dapat dibentuk hanya dengan pelajaran, instruksi dan larangan. Menanamkan sopan santun memerlukan pendidikan yang panjang. Pendidikan itu tidak akan sukses jika disertai pemberian contoh teladan yang baik dan nyata.

(Nata, 2003: 164-165)

\section{c. Metode Nasihat (Mauidhah)}

Pemberian nasihat kepada siswa merupakan salah satu cara untuk membentuk akhlaknya. Mauidzah berarti nasihat. Rasyid Ridha mengartikan mauidzah adalah nasihat peringatan atas kebaikan dan kebenaran dengan jalan apa saja yang dapat menyentuh hati dan membangkitkannya untuk mengamalkan dalam al-Qur'an juga menggunakan kalimat-kalimat yang menyentuh hati untuk mengarahkan manusia kepada ide yang dikehendakinya.

\section{KESIMPULAN}

Sekolah sebagai lembaga yang berkewajiban untuk membimbing siswa menjadi manusia yang tangguh, bermoral dan pekerja keras harus mempunyai terobosan-terobosan dalam membina akhlak siswa, terlebih bagi jenjang sekolah dimana siswanya sedang dalam masa pubertas. Kegiatan yang dilakukan oleh SMP Tri Bhakti Tegaldlimo Banyuwangi sebagai usaha untuk mendampingi siswa melalui masa puber ini merupakan paket yang komplit karena dilakukan melalui beberapa metode. Metode pembiasaan lewat kegiatan keagamaan, penambahan wawasan pengetahuan seputar masa pubertas, dan kegiatan pendampingan keterampilan bakat dan minat. Selain bentuk pembiasaan, juga tidak lupa dibekali dengan pemberian teladan oleh para guru melalui kegiatan kedisiplinan dan yang paling penting lagi adalah pemberian nasihat.

Metode-metode inilah yang merupakan jawaban dari permasalahan pendidikan remaja masa kini. Sekolah sebagai orang tua tidak hanya menjejali siswa dengan aneka rupa wacana teoritis, tetapi juga memberikan fasilitas sebagai pembentuk akhlakul karimah para peserta didiknya.

\section{DAFTAR PUSTAKA}

Al-Abrasy, Muhamad Al-Athiyah. (1970). Dasar-Dasar Pokok Pendidikan Islam,Terj. Bahri, Bustoni A. Ghoni dan Jauhar. Jakarta : Bulan Bintang.

Amin, Ahmad. (1995). Etika (Ilmu Akhlak). Jakarta: Bulan Bintang.

A.M, Sardiman. (2011). Intraksi dan Motivasi Belajar Mengajar. Jakarta: Raja Grafindo Persada

Arikunto, Suharsimi. (2006). Prosedur Penelitian Suatu Pendekatan Praktik, Jakarta: Rineka Cipta

Asrori, Muhammad \& Muhammad Ali. (2005). Psikologi Remaja: Perkembangan Peserta Didik, Jakarta: Bumi Aksara.

Azizy A. Qodri. (2003). Pendidikan untuk Membangun Etika Sosial: Mendidik Anak Sukses Masa Depan : Pandai dan Bermanfaat, Jakarta : Aneka Ilmu

Basri, Hasan. (2004). Remaja Berkualitas:

Problematika Remaja dan Solusinya, Yogyakarta: Mitra Pustaka.

Hurlock, Elizabeth. B. (2004). Psikologi Perkembangan: Suatu Pendekatan Sepanjang Rentang Kehidupan, Jakarta : Erlangga.

Danim, Sudarwan. (2003).Agenda Pembaharuan Sistem Pendidikan, Yogyakarta: Pustaka Pelajar

Departemen Agama RI. (2011). Al-Qur'an dan Terjemahannya, Bandung: Mizan Bunaya Kreativa

Desmita. (2005). Psikologi Perkembangan, Bandung: Remaja Rosdakarya.

Djatnika, Rahmat. (1996). Sistem Etika Islami, Jakarta: Pustaka Panjimas.

Gunawan, Heri. (2012). Pendidkan Karakter. Bandung: Alfa Beta. 
Hartati, Netty, dkk. (2005). Islam dan Psikologi. Jakarta: Raja Grafindo Persada.

Iman al-Ghazali. Ihya' Ulumuddin Juz III. Beirut: Dar Ihya al-Kutub al-Ilmiyah, t.th.

Iskandarwasid. (2010). Strategi Pembelajaran Bahasa. Bandung: Remaja Rosda Karya.

Mahmud, Ali Abdul Halim. (2004).alTarbiyah al-Khuluqiyah.Jakarta: Gema Insani Press.

Majid, Abdul \& Muhaimin. (1999). Pemikiran Pendidikan Islam. Bandung: Trigenda Karya.

Mukhtar. (2003). Desain Pembelajaran Pendidikan Agama Islam, Jakarta: Misaka Galiza.

Moleong, Lexy J. (2000). Metodologi Penelitian Kualitatif. Bandung: Remaja Rosda Karya.

Nata, Abudin. (2002). Akhlak Tasawuf. Jakarta: Rajawali Press.

Ridha, Akram. (2006). Manajemen Pubertas Panduan Ampuh Orangtua Melejitkan Kepercayaan Diri Remaja.Bandung : Syaamil Cipta Media.

Sa'aduddin, Imam \& Abdul Mukmin. (2006). Meneladani Akhlak

Nabi: Membangun Kepribadian Muslim.Bandung: Remaja Rosdakarya

Shaleh, Munawar. (2005). Politik Pendidikan : Membangun Sumber Daya Bangsa dengan Peningkatan Kualitas Pendidikan, Jakarta : Grafindo Khazanah Ilmu.

Shihab, M. Quraish. (2004). Tafsir AlMishbah : Pesan, Kesan dan Keserasian Al-Qur'an. Jakarta: Lentera Hati.

Sinaga, Hasanuddin \& Zahruddin AR. (2004). Pengantar Studi Aklak, Jakarta: Raja Grafindo Persada.

Sudarsono. (1989). Etika Tentang Kenakalan Remaja, Jakarta: Bina Aksara,

Sugiyono. (2007). Memahami Penelitian Kualitatif. Bandung: Alfa Beta.

Sukmadinata, Nana Syaodih et al, 2008, Pengendalian Mutu Sekolah Menengah; Konsep, Prinsip dan Instrumen, Bandung: PT.Refika Aditama.

Uhbiyati, Nur. (2005). Ilmu Pendidikan Islam. Bandung: Pustaka Setia.

Usman, Moh. Uzer. (2000). Menjadi Guru Profesional, Bandung: Remaja Rosda Karya.

Yaqub, Hamzah. (1993). Etika Islam. Bandung: Diponegoro.
Zarkasih Putro, Khamim. 2017. Memahami Ciri dan Tugas Perkembangan Masa Remaja. Aplikasia:Jurnal Aplikasi Ilmu-Ilmu Agama, Vol.17, No.1. Yogyakarta: UIN Sunan Kalijaga Yogyakarta 